\title{
ANALISIS PERBEDAAN KUALITAS ACCRUAL ANTARA SEBELUM DAN SESUDAH PENGADOPSIAN INTERNATIONAL FINANCIAL REPORTING STANDARD (IFRS) PADA PERUSAHAAN MANUFAKTUR DI INDONESIA(Studi Empiris pada Perusahaan Manufaktur yang terdapat di Bursa Efek Indonesia Tahun 2009-2014)
}

\author{
Esti Windarti ${ }^{1}$ \\ *Program Studi, Fakultas, Universitas \\ *windarti.esti@yahoo.co.id ${ }^{l}$ \\ Noer Sasongko ${ }^{2}$ \\ * Fakultas Ekonomi dan Bisnis, Universitas Muhammadiyah Surakarta \\ *noer_sasongko@ums.ac.id ${ }^{2}$ \\ Zulfikar $^{3}$ \\ * Fakultas Ekonomi dan Bisnis, Universitas Muhammadiyah Surakarta \\ *zulfikar@ums.ac.id
}

\begin{abstract}
The purpose of this study to examine the numbers between the accrual quality difference before and after adopting International Financial Reporting Standards (IFRS). The population in this study are all manufacturing companies listed in Indonesia Stock Exchange 2009-2014. Sampling using purposive sampling selection of samples with specific criteria.

Analysis of the data used is by using normality test and analysis methods paired sample t-test. Calculation of accruals quality using the 2 models that Dechow and Dichev Model and Modified Jones Models. From the test results showed that there was a difference in quality between the accrual before and after adopting International Financial Reporting Standard (IFRS) for 2009-2014 by using Dechow and Dichev Model, while contrary to the results of testing using the Modified Jones Model. The difference is due to the result of the absence of a change in accounting rules and the transition period that occurred in Indonesia.
\end{abstract}

Keywords: Quality acrual, International Financial Reporting Standard ( IFRS ), Manufacturing Company, Paired Sample T-test

\section{Pendahuluan}

IFRS (International Financial Reporting Standards) menjawab tantangan bagaimana pelaporan keuangan harus dilakukan. Arus besar dunia sekarang ini sedang menuju ke dalam satu standar pelaporan. Satu per satu negara di dunia saat ini mulai mengadopsi IFRS. Ikatan Akuntan Indonesia (IAI) sebagai organisasi yang berwenang dalam membuat standar akuntansi di Indonesia sejak 1994 telah melaksanakan program adaptasi dan harmonisasi standar akuntansi internasional IFRS. Pengadopsian IFRS di Indonesia dimulai pada tahun 2008 dimana dilakukan adopsi seluruh IFRS terakhir ke dalam PSAK sampai tahun 2010. Pada tahun 2011 dilakukan persiapan infrastruktur pendukung untuk implementasi PSAK yang sudah mengadopsi IFRS dan tahun 2012 pengadopsian penuh IFRS bagi perusahaan-perusahaan yang memiliki akuntabilitas publik (Purba, 2010).

Terdapat beberapa keuntungan dalam mengadopsi IFRS yaitu memudahkan pemahaman atas laporan keuangan dengan penggunaan Standar Akuntansi Keuangan yang dikenal secara internasional (enhance comparability). Meningkatkan arus investasi global melalui transparansi. Menurunkan biaya modal dengan membuka peluang fund raising melalui pasar modal secara global. Menciptakan efisiensi penyusunan laporan keuangan (Wirahardja, 2010). Terdapat kelemahan dalam mengadopsi IFRS yang diantaranya adalah Dewan Standar Akuntansi yang kekurangan sumber daya, IFRS berganti terlalu cepat sehingga ketika proses 
adopsi suatu standar IFRS masih dilakukan, pihak IASB sudah dalam proses mengganti IFRS tersebut. Kendala bahasa, karena setiap standar IFRS harus diterjemahkan ke dalam bahasa Indonesia. Infrastuktur profesi akuntan yang belum siap. Untuk mengadopsi IFRS banyak metode akuntansi yang baru yang harus dipelajari lagi oleh para akuntan. Kesiapan perguruan tinggi dan akuntan pendidik untuk berganti kiblat ke IFRS. Support pemerintah terhadap issue konvergensi (Hidayat, 2011).

IFRS merupakan standar yang menggunaan Principle Based dalam perlakuan akuntansi. Penggunaan principle based akan mengurangi kemungkinan munculnya aturan baru yang melengkapi aturan yang sudah ada. Munculnya aturan-aturan baru akan memberikan kesempatan kepada manajemen melakukan income smoothing yang memicu munculnya manajemen laba. Konvergensi IFRS menuntut manajemen untuk mengungkapkan informasi akuntansi lebih rinci dan detail. Pengungkapan dalam laporan keuangan harus sejalan dengan informasi yang dipakai untuk pengambilan keputusan yang diambil oleh manajemen. Tingkat pengungkapan yang lebih rinci dan detail mendekati pengungkapan penuh (full disclosure) akan mengurangi tingkat asimetri informasi akuntansi antara manajer dan pengguna laporan keuangan. Asimetri informasi merupakan bentuk penyimpangan yang dilakukan oleh manajer terkait dengan informasi pengukuran kinerja manajer. FASB melalui statement of Financial Accounting Concept No. 2 (Kieso dan Weygandt, 2007:37-38) menetapkan karakteristik kualitatif informasi akuntansi meliputi kualitas primer yaitu relevansi dan reliabilitas, kualitas sekunder meliputi komparabilitas dan konsistensi. Informasi dari berbagai perusahaan dianggap memiliki komparabilitas jika telah diukur dan dilaporkan dengan cara yang sama. Komparabilitas memungkinkan pemakai mengidentifikasi persamaan dan perbedaan riil dalam peristiwa ekonomi antar perusahaan. Perusahaan dianggap konsisten jika mengaplikasikan perlakuan akuntansi yang sama untuk kejadiankejadian serupa dari periode ke periode. Perusahaan dapat mengganti satu metode akuntansi dengan metode metode akuntansi yang lain, dengan syarat perusahaan harus dapat menunjukkan bahwa metode yang baru lebih baik daripada metode sebelumnya.

Pada tanggal 1 Januari 2012, IAI menetapkan Standard Akuntansi di Indonesia mengadopsi penuh
IFRS pada perusahaan-perusahaan go public yang terdapat di Bursa Efek Indonesia. Perubahan mendasar pada SAK setelah adopsi IFRS diduga dapat menyebabkan terjadinya perbedaan kualitas laba antara sebelum dan sesudah adopsi IFRS. Standar dengan principle based yang tidak menekankan pada aturan baku dan banyak menggunakan judgement menyebabkan suatu penilaian akuntansi didasarkan pada pandangan subyektif, sehingga memungkinkan peluang manajemen laba yang berbeda. Selain itu setelah adopsi IFRS, PSAK menjadi lebih banyak menggunakan nilai wajar (fair value) dan memungkinkan perbedaan kualitas laba, karena selisih nilai wajar yang langsung diakui dalam laporan laba rugi.

Dalam proses penyusunan laporan keu $\neg$ angan, dasar akrual memungkinkan adanya pe $\neg$ rilaku manajer dalam melakukan rekayasa laba guna menaikkan atau menurunkan angka akrual dalam laporan laba-rugi. SAK memberikan ke longgaran dalam memilih metode akuntansi yang digunakan oleh tiap perusahaan dalam pe-nyusunan laporan keuangan.Kelonggaran daᄀlam metode ini yang dapat dimanfaatkan untuk menghasilkan nilai laba yang berbeda-beda di tiap perusahaan. Perusahaan yang memilih me tode penyusutan garis lurus akan berbeda hasil laba yang dilaporkan dengan perusahaan yang menggunakan metode angka tahun atau saldo menurun. Praktik seperti ini dapat memberikan dampak terhadap kualitas laba yang dilaporkan.(Boediono, 2005).

Francis et al. (2005) menggunakan kualitas akrual sebagai ukuran dari risiko informasi yang berkaitan dengan laba. Alasannya yaitu dengan menggunakan kualitas akrual dapat dilihat seberapa besar ketepatan working capital accruals menjadi realisasi arus kas operasi sehingga dapat dilihat kualitas laba yang dilaporkan perusahaan. Penggunaan model kualitas akrual tersebut berdasarkan dari prinsip akuntansi yaitu basis akrual. Pendapatan dan beban merupakan komponen akrual yang pengakuannya berdasarkan kriteria tertentu. Salah satu kriteria pengakuan pendapatan yaitu pendapatan diakui bila kemungkinan besar manfaat ekonomi masa depan akan mengalir ke entitas dan manfaat ini dapat diukur dengan andal. Pengakuan pendapatan dan beban tersebut melibatkan estimasi, pilihan kebijakan akuntansi, dan justifikasi manajemen. Berkaitan dengan estimasi tersebut, kualitas akrual dipengaruhi oleh perhitungan kesalahan (error) dalam nilai 
estimasi akrual, terlepas dari faktor intensi manajemen. Francis et al. (2005) memberikan bukti empiris bahwa kualitas akrual yang buruk akan meningkatkan risiko informasi dan akan meningkatkan biaya modal.

Hasil penelitian lainnya dari Francis et al. (2005) yaitu mengenai komponen kualitas akrual yang terdiri dari dua yaitu faktor diskresioner dan faktor innate. Faktor diskresioner merupakan komponen kualitas akrual yang merefleksikan pilihan kebijakan manajemen, misalnya berupa praktik manajemen laba untuk memanipulasi laba perusahaan dalam pelaporan laporan keuangan. Sedangkan faktor innate merupakan komponen kualitas akrual yang merefleksikan faktor lingkungan, fundamental ekonomi, atau model bisnis perusahaan. Salah satu contoh faktor innate yaitu ketika ada peningkatan pendapatan perusahaan debitur, maka perusahaan bisa saja mengubah dan melakukan penyesuaian estimasi pengakuan piutang tak tertagih terhadap piutang debitur tersebut. Hasil penelitian Francis et al. (2005) mengenai perbedaan kedua komponen kualitas akrual tersebut terhadap biaya modal yaitu kualitas akrual innate lebih besar pengaruhnya dibandingkan kualitas akrual diskresioner terhadap biaya modal, baik biaya utang maupun biaya ekuitas.

Berdasarkan penjelasan diatas, maka rumusan penelitian ini adalah : Apakah terdapat perbedaan kualitas accrual antara sebelum dan sesudah mengadopsi International Financial Reporting Standard (IFRS). Berdasarkan rumusan masalah di atas, peneliti memiliki tujuan sebagai berikut: Menganalisis kualitas accrual antara perbedaan sebelum dan sesudah mengadopsi International

\section{Financial Reporting Standard (IFRS).}

\section{Metode Penelitian}

Sumber data yang digunakan dalam penelitian ini adalah data sekunder yang diperoleh dari Indonesian Stock Exchange (IDX) tahunan tahun 2009-2014.Populasi penelitian ini adalah perusahaan manufaktur yang terdaftar yang terdaftar di Bursa Efek Indonesia (BEI). Sampel ditentukan dengan menggunakan metode purposive sampling dengan kriteria yang ditentukan. Berikut ini kriteria yang ditentukan :

1. Perusahaan yang terdaftar di Bursa Efek Indonesia selama periode 2009-2014
2. Perusahaan mempublikasikan laporan keuangan tahunan untuk periode 31 Desember 2009-31 Desember 2014 secara berturut-turut dan dinyatakan dalam rupiah ( $\mathrm{Rp})$.

3. Data yang tersedia lengkap (data secara keseluruhan tersedia pada publikasi periode 31 Desember 2009-31 Desember 2014.

\section{Definisi Operasional dan Pengukuran Variabel}

\section{a. Variabel Kualitas Akrual}

Teruel et al. (2009) menyatakan bahwakualitas akrual adalah kualitas informasi akuntansi yang disajikan perusahaan yang membandingkan antara akrual dengan arus kas perusahaan pada periode masa lalu, sekarang dan masa depan. Kualitas akrual dikatakan baik jika akrual memiliki kedekatan dengan aliran kas perusahaan di masa depan (Dechow dan Dichev 2002).

\section{b. Pengukuran variabel}

\section{'Model 1 (Dechow and Dichev model)}

Pendekatan accruals-cashflow mengacu Dechow dan Dichev (2002) dihitung dengan rumus sebagai berikut:

$$
\begin{aligned}
& \text { TT_ACCR }=\alpha+\beta 1 \text { CFOt-1 + }+\beta 1 \text { CFOt }+\beta 3 \\
& \text { CFOt }+1+\beta 4 \Delta \text { REV }+\beta 5 \text { PPE }+e
\end{aligned}
$$

a) Menghitung besarnya total kualitas akrual

TT_ACCR $=\{(\triangle \mathrm{AR}(\mathrm{RECT})+\Delta$ Inventory (INVT) $+\Delta$ Other Current Asset (ACT) $-\Delta$ AP$\Delta \mathrm{TP}(\mathrm{TXP})-\Delta$ Other Current Liabilities (LCT)Depreciation (DP) $\} /$ Average Total Asset (AT)

$\triangle \mathrm{AR}(\mathrm{RECT})=$ Piutang Dagang

$\Delta$ Inventory $($ INVT $)=$ Persediaan Barang Dagang

$\Delta$ Other Current Asset $($ ACT $)=$ Asset Lancar Lainnya

$\triangle \mathrm{AP}$ (Account Payable) $=$ Utang Dagang

$\Delta \mathrm{TP}($ Tax Payable $)=$ Hutang Pajak

$\Delta$ Other Current Liabilities $(\mathrm{LCT})=$ Hutang

Lancar Lainnya

Depreciation $(\mathrm{DP})=$ Depresiasi

Average Total Asset $(\mathrm{AT})=$ Rata - Rata Total

Asset

b) Menghitung besarnya CFO (Cash Flow Operation $)=$ Arus Kas Operasi

CFO (t-1) = Arus Kas Operasi sebelum tahun $\mathrm{t}$

$\mathrm{CFO}(\mathrm{t})=$ Arus Kas Operasi pada tahun $\mathrm{t}$ 
$\mathrm{CFO}(\mathrm{t}+1)=$ Arus Kas Operasi setelah tahun $\mathrm{t}$

c) Menghitung $\triangle$ REV (Revenue) $=$ Perubahan Pendapatan g. $\alpha=$ Koefisien regresi

Masing-masing variabel dari komponen rumus di atas dibagi dengan rata-rata total aktiva perusahaan. Dari persamaan regresi tersebut diambil nilai residual. Nilai $\triangle R E V=$ Pendapatan pada tahun $(t)-$ Pendapatan sebelumyrefidual kemudian diabsolutkan sehingga semakin

\section{Rata- Rata Total Asset}

d) Menghitung PPE=Aset Tetap

PPE=Aset Tetap/rata-rata total aset

Untuk mencari nilai kualitas accrual dengan cara mengregresikan variabel tersebut, dan kemudian diabsolutkan sehingga nilai tersebut merupakan nilai kualitas accrual

Model 2 (Model Jones)

a) Mencari nilai total accrual (TAit)

\section{TAit $=$ Nit - CFOit}

Keterangan :

1. $\quad$ TAit $=$ Total akrual perusahaan i pada periode ke $\mathrm{t}$

2. Nit $=$ Laba bersih perusahaan i pada periode ke $\mathrm{t}$

3. CFOit $=$ Aliran kas dari aktivitas operasi perusahaan i pada periode ket

b) Nilai total accrual (TA) yang diestimasi dengan persamaan regresi OLS sebagai berikut :

TAit $=\alpha 0(1 /$ Ait-1) $+\alpha 1(\Delta$ Revit /Ait-1 $\Delta$ Recit /Ait-1) $+\alpha 2$ (PPEit/ Ait1)

c) Berdasarkan koefisien regresi diatas, nilai non discretionary accrual (NDA) dapat dihitung dengan rumus :

NDAit $=\alpha 0(1 /$ Ait-1 $)+\alpha 1(\Delta$ Revit $/$ Ait-1 $\Delta$ Recit/Ait-1) $+\alpha 2$ (PPEit/Ait1)

d) Selanjutnya discretionary accrual (DA) dapat dihitung sebagai berikut :

1. DAit $=$ TAit - NDAit

Keterangan:

a. $\quad$ DAit $=$ Discretionary accruals perusahaan $\mathrm{i}$ pada periode ke $\mathrm{t}$

b. NDAit =Non discretionary accruals perusahaan i pada periode ke $t$

c. Ait-1 = Total aktiva perusahaan i pada periode ke $\mathrm{t}-1$

d. $\Delta$ Revit $=$ Perubahan pendapatan perusahaan i pada periode ke $t$

e. $\quad \Delta$ Reci $\mathrm{t}=$ Perubahan piutang perusahaan $\mathrm{i}$ pada periode ke $t$

f. $\quad$ PPEit $=$ Aktiva tetap perusahaan i pada periode ke $\mathrm{t}$ rendah nilai absolut residual, semakin tinggi kualitas akrual.Setelah didapatkan nilai TCA, CFO, REV, dan PPE maka seluruhnya dibagi dengan total aset pada tahun $(\mathrm{t})$.

\section{c. Sampel}

Pemilihan sampel dilakukan dengan metode Purposive Sampling. Hasil pemilihan sampel yang memenuhi kriteria pemilihan adalah terdapat beberapa perusahaan dengan jenis Industri Manufaktur di Indonesia.

\begin{tabular}{|c|c|c|c|}
\hline Keterangan & $\begin{array}{c}\text { Sebelum } \\
\text { IFRS } \\
\text { 2009-2011 }\end{array}$ & $\begin{array}{c}\text { Setelah } \\
\text { IFRS } \\
2012-2014\end{array}$ & Jumlah \\
\hline $\begin{array}{l}\text { Jumlah Perusahaan Manufaktur yang } \\
\text { terdaftar di BEI }\end{array}$ & 152 & 442 & 594 \\
\hline $\begin{array}{l}\text { Perusahaan yang tidak menerbitkan } \\
\text { laporan keuangan secara berturut turt }\end{array}$ & (33) & (128) & 433 \\
\hline $\begin{array}{l}\text { Perusahaan yang tidak menggunakan } \\
\text { mata uang rupiah }\end{array}$ & $(25)$ & $(100)$ & 308 \\
\hline $\begin{array}{l}\text { Perusahaan yang tidak memiliki data } \\
\text { secara lengkap dan tidak mengadopsi }\end{array}$ & (66) & (186) & 56 \\
\hline \multicolumn{4}{|l|}{ IFRS } \\
\hline & 28 & 28 & \\
\hline Jumlah Sampel (28x3) & 84 & 84 & \\
\hline
\end{tabular}

\section{Hasil dan Pembahasan \\ Hasil Uji Normalitas}

\begin{tabular}{llrlr}
\hline Keterangan & Model Dechow & \multicolumn{2}{l}{ Model Jones } \\
\hline Sebelum IFRS & & .000 & .000 \\
Setelah IFRS & & .000 & .000 \\
Kesimpulan & Signifikasi $<0,05$ (data & Signifikasi $<0,05$ (data \\
& tidak & berdistribusi & tidak & berdistribusi \\
& normal) & & normal) & \\
& & & &
\end{tabular}

Kesimpulan dari hasil perhitungan tersebut adalah nilai probabilitas lebih dari<0,05, sehingga menunjukkan bahwa distribusi data dalam penelitian ini adalah tidak berdistribusi normal.

\section{Hasil Uji Hipotesis}

Pengujian hipotesis pada penelitian ini menggunakan alat uji t-test. Metode tersebut termasuk 
dalam golongan statistik parametrik dan alat uji ini digunakan untuk pengujian hipotesis pada penelitian yang ingin mengetahui uji beda dari variable yang diteliti. Teknik analisis data yang digunakan pada penelitian ini adalah uji beda rata-rata dengan uji-t (paired sample t-test) untuk membandingkan rata-rata dari dua sampel yang berpasangan yaitu untuk melihat apakah berbeda atau sama pada tingkat signifikan $\square=$ 0,05 dan akan meningkatkan biaya modal. Sellami dan Fakhfakh (2014) membandingkan diskrisionery akrual perusahaan yang listing di 11 pasar Eropa sesaat setelah pengadopsian IFRS. Mereka menemukan bahwa IFRS mendukung diskresionery akuntansi dan perilaku opertunistik.

\section{UJI T(UJI BEDA)}

\section{Simpulan}

Kesimpulan dari penelitian ini adalah:

\begin{tabular}{lll}
\hline Keterangan & Rumus l(model dechow) & Rumus 2(model jones). \\
\hline T & 2,730 & $-1,217$ \\
Sig (2-tailed) & 0,008 & 0,216 \\
Kesimpulan & Ada perbedaaan & Tidak ada perbedaan \\
& Signifikasi $<0,05$ & Signifikasi $>0,05$ \\
\hline
\end{tabular}

Terdapat perbedaan mengenai kualitas akrual pada perusahaan-perusahaan manufaktur antara sebelum dan sesudah mengadopsi International Financial Reporting Standard (IFRS) pada Dechow and Dichev model.

Dari hasil penelitian model dechow menunjukkan bahwa terdapat perbedaan antara kualitas accrual sebelum dan sesudah pengadopsian IFRS di Indonesia. Hasil penelitian ini sejalan dengan penelitian Liu et al.,(2011), di Cina, dan Chua et al.,(2012) di Australia menunjukkan hasil yang sama, yaitu setelah adopsi IFRS kualitas akuntansi semakin meningkat, meningkatnya relevansi nilai, dan lebih seringnya pengakuan kerugian dan hasil penelitian Daske dan Gunther (2006) menyatakan bahwa pengadopsian IFRS meningkatkan kualitas financial statement. Hasil penelitian ini tidak sejalan dengan hasil penelitian Meulen (2007) dan Karampinis dan Hevas (2011), tidak ada perubahan signifikan dalam kualitas informasi akuntansi sebelum dan sesudah adopsi IFRS.

Dari hasil penelitian model jones menunjukkan bahwa tidak adanya perbedaan antara kualitas accrual sebelum dan sesudah pengadopsian IFRS di Indonesia.Dikarenakan pertama bahwa kualitas akrual sangat berkaitan dengan aturan akuntansi yang tidak mengalami perubahan.Kedua adanya masa transisi dalam penerapan IFRS di Indonesia antara sebelum dan sesudah pengadopsian. Ketiga pada dasarnya batang tubuh dari kerangka konseptual yang masih sama sehingga pada kualitas akrual tidak terjadi perbedaan baik sebelum dan sesudah IFRS.

Hasil ini tidak sesuai dengan penelitian Francis et al. (2005) memberikan bukti empiris bahwa kualitas akrual yang buruk akan meningkatkan risiko informasi
2. Tidak terdapat perbedaan mengenai kualitas akrual pada perusahaan-perusahaan manufaktur antara sebelum dan sesudah mengadopsi International Financial Reporting Standard (IFRS) pada Modified Jones Models.

Keterbatasan dan Saran Penelitian

1. Hasil dari penelitian ini hanya sebatas untuk mengetahui adanya perbedaan atau tidak pada kualitas akrual di perusahaan-perusahaan manufaktur antara sebelum dan sesudah pengadopsian International Financial Reporting Standard (IFRS), sehingga dalam penelitian selanjutnya bisa di perluas ke variabel lainnya.

Populasi dan sampel penelitian yang digunakan hanya terbatas pada jenis perusahaan manufaktur saja, sehingga tidak dapat digerenalisasikan pada populasi atau sampel jenis perusahaan lain.

\section{Referensi}

[1] Aboody, David, John Hughes, and Jing Liu. 2005. Earnings Quality, Insider Trading, and Cost of Capital. Journal of AccountingResearch, 43 (5), 651-671

[2] Anggraita, Viska, 2012. Dampak Penerapan PSAK 50/55 (Revisi 2006) Terhadap Manajemen Laba di Perbankan. SNA : 15,107-SIPE-51

[3] Barth, M., W. R. Landsman, and M. Lang. 2008. "International Accounting Standards and Accounting Quality."Journal of Accounting Research 6, pp. 159-178. 
[4] Beidleman CR.1973. Income Smoothing : The Role of Manajemen .The Accounting Reviev : 48(4), 653-68

[5] Belkaoui, A.R. 2000. Teori Akuntansi. Jakarta : Salemba Empat.

[6] Boediono, SB., Gideon. 2005. "Kualitas Laba : Studi Pengaruh Mekanisme Corporate Governance dan Dampak Manajemen Laba dengan Menggunakan Analisis Jalur". Simposium Nasional Akuntansi X.

[7] Butler, Marty et al.2004. An Empirical Analysis of Auditor Reporting and Its Association with Abnormal Accruals. Jurnal of Accounting and Economics 37,139-165

[8] Cahyonowati, Nur dan Dwi Ratmono.2012.Adopsi IFRS dan Relevansi Nilai Informasi Akuntansi. Jurnal Akuntansi dan Keuangan, Vol. 14, No. 2, 105-115

[9] Dechow, P.M.; R.G. Sloan; and A.P. Sweeney. 2005. "Detecting Earnings Management." The Accounting Review, Vol. 70, April: 193 - 225.

[10] Ewert dan Wagenhof. 2005. Economic Effects of Tightening Accounting Standards to Restrict Earnings Management. The Accounting Review. Vol.80 P.1101-1124

[11] Francis, J.; R. LaFond; P.M. Olsson; and K. Schipper. 2004. "Costs of Equity and Earnings Attributes." The Accounting Review, Vol. 79, No. 4, Oktober: $967-1010$.

[12] Gamayuni, Rindu Rika 2009. Perkembangan Standard Akuntansi Keuangan Indonesia Menuju International Financial Reporting Standards, Jurnal Akuntansi dan keuangan 14,153-166

[13] Glory A dan Marsono 2013, Analisis Komparasi Kualitataif Informasi Akuntansi Sebelum Dan Sesudah Pengadopsian Penuh IFRS Di Indonesia, Jurnal Akuntansi UNDIP Semarang,Vol.2, N0.3, hal 1

[14] Goncharov dan Zimmerman, 2006, Do Accounting Standard Influence the Level of Earning Management Evidence from Jermany. http://www.ssrn.com diakses tanggal 2 April 2015

[15] Ghozali, Imam dan Chariri, Anis. 2007. Teori Akuntansi, Edisi Tiga.Semarang : Badan Penerbit Universitas Diponegoro

[16] Ghozali Imam. 2012, Aplikasi Analisis Multivariate Dengan Program IBM SPSS 20, Semarang : Badan penerbit Universitas Diponegoro

[17] Gray, Philip, Ping-Sheng Koh, and Yen H.Tong. 2008. Accruals Quality, Information Risk and Cost of Capital: Evidence from Australia. Journal of Business Finance \& Accounting, 36(1), 51-72.
[18] Hidayat, 2011. Konvergensi IFRS di Indonesia.

(http://imanfreelance.blogspot.com/2011/05/ko nvergensi-ifrs-diindonesia.). Diakses tgl 25 september 2013.

[19] Ikatan Akuntansi Indonesia. 2012. Standar Akuntansi Keuangan. Jakarta Selemba Empat.

[20] Jeanjean,T. dan Stolowy, H. (2008). Do Accounting Standards Matter? An ExploratoryAnalysis of Eanings Management Before and After IFRS Adoption. Jurnal of Accounting and Public Policy, 27, 480-494

[21] Juan,Ng Nng,Wahyuni Ersa Tri (2013), Panduan Praktis Standar Akuntansi Keuangan, Salemba Empat Jakarta

[22] Karampinis, N. dan Hevas, D.2011. Mandating IFRS in an Unfavorable Enviroment: The Greek Experience. The International Journal of Accounting, 46, 304-332

[23] Kieso, Donald E. dan Weygandt, 2007. "Akuntansi Intermediate" Jilid I, Edisi Keduabelas, Jakarta:Penerbit Erlangga

[24] Krismiaji, et al .,2013. Pengaruh Adopsi International Financial Reporting Standard Terhadap kualitan Informasi Akuntansi. ISSN : 0853-1259, Vol 24, No.2, Hal.63-71

[25] Kustina,Ketut Tanti, 2012. Dampak Konvergensi International Financial Reporting Standard (IFRS) Bagi Pelapoe Akuntan Perusahaan di Indonesia. Jurnal Ilmiah Manajemen Dan Akuntansi STIE Triatma Mulya : Vol 17, No 2 Hal 70-82

[26] Martani, Dwi., 2011. Dampak Implementasi IFRS Bagi Perusahaan. Jurnal Akuntansi Keuangan ISSN 2088-8317/No. 48 tahun V Juli 2011, hal. 98-99

[27] Mujiono, 2010. Pengaruh Tindakan Perataan Laba Terhadap Reaksi Pasar dengan Kualitas Auditor dan Kepemilikan Majerial Sebagai Variabel Pemoderasi. Eksplanasi Vol.5 No.2

[28] Meulen, van der, S., Gaeremynck, A., dan Willekens, M.2007. Attribute Differences Between US GAAP and IFRS Earnings: An exploratory study. The International Journal of Accounting, 42(2), 123-142

[29] Nandakumar, Kalpesh J.Mehta (2012). Memahami IFRS Standar Pelaporan Keuangan Internasional, PT Indeks Jakarta

[30] Nelson, M.W.J.A Elliot and R.L Tarpley. 2000."Where Do Companies Attempt Earning Managemen, and When Do Auditors Prevent It? ' 'http://papers.ssrn.com.

[31] Nurisya, Maulidya dan Wardoyo. 2013. Analisis Perbandingan Kinerja Perbankan yang Mengadopsi Standar pelaporan Keungan Internasional. ISSN : 1858-2559, Vol.5 :24-30 
[32] Roychowdhury, Sugata. (2006). Earnings Management Through Real Activities Manipulation. Jurnal of Accounting and Economic, 42,335-370

[33] Senjani, Yaya Putri. (2012). Manajemen Laba Berbasis Akrual dan Riil Sebelum danSetelah Adopsi IFRS. Tesis :Universitas Gajah Mada Yogyakarta

[34] Petreski, Marjan, 2006. The Impact of International Accounting Standard on Firms.http://papers.ssm.com/sol3/papers.cdm? abstract_id=901301. Diakses tanggal11 April 2015

[35] Purba, Marisi P.2010. IFRS : Konvergensi dan Kendala Aplikasinya di Indonesia. Yogyakarta Graha Ilmu

[36] Rohaeni, Dian, dan Titik Aryani. 2011. Pengaruh Konvergensi IFRS terhadap Income Smoothing dengan kualitas Audit Sebagai Variabel Moderasi. SNA : 15, 100-SIPE-22

[37] Rudianto. 2009. Pengantar Akuntansi. Erlangga Jakarta

[38] Scott, William R.2009. Financial Accounting Theory. Fifth Edition.Canada Prientice Hall.

[39] Shipper, K.1989. Commentary on Earnings Managements. Accounting Horizons 3,91-102

[40] Sianiapar, G.A.E.M. (2013), Analisis Komparasi Kualitas Informasi Akuntansi Sebelum dan Sesudah Pengadopsian Penuh IFRS di Indonesia. Journal of Accounting. ISNN (Online): 2337-3806, Vol.2, No.3, Hal.1

[41] Sugiyono. 2005. Metode Penelitian Bisnis. Alfabeta CV. Bandung

[42] Teruel et al, 2009. Accruals Qualityand Corporate Cash Holdings. Journal compilation Accounting and Finance, 49 (1), 95-115.

[43] Trisnawati, Rina, Wiyadi dan Noer Sasongko. 2012. Pengukuran Manajemen Laba Pendekatan Terintegrasi ( Studi Komparatif Perusahaan Manufaktur yang tergabung pada indek JII dan dan LQ45.Bursa efek Indonesia periode (2004-2010). Bursa Effek Indonesia periode 2004-2010). SNA 15 : 039AKPM-71.

[44] Wiley, 2007, Interpretation and Aplication of International Financial Reporting Standard, IFRS

[45] Wirahardja, R.I., (2010). Adopsi IAS 41 dalam Rangkaian Konvergensi IFRS di Indonesia. Ikatan Akuntansi Indonesia. 